\title{
IS THERE A CLINICAL PATHOLOGICAL CORRELATION OF COLORECTAL ADENOCARCINOMA WITH THE IMMUNOHISTOCHEMICAL EXPRESSION OF OPN AND ABCB5?
}

\author{
Há correlação clínicopatológica do adenocarcinoma colorretal com a expressão imunoistoquímica do OPN e \\ $A B C B 5$ ?
}

Diogo Francesco CASTOLDI ${ }^{1,8}{ }^{\bullet}$, Osvaldo MALAFAIA ${ }^{1,3,8}{ }^{\circ}$, Pedro Helo dos SANTOS-NETO ${ }^{20}$, Tatiana Varella POSTIGLIONI ${ }^{2}{ }^{\circ}$, Cecilia VASCONCELOS ${ }^{4 \oplus}$, Fabiola Past BREMER ${ }^{5 \odot}$, Leticia Elizabeth Augustin CZECZKO $^{4 \oplus}$, Martin GASSER ${ }^{6 \oplus}$, Ana Maria WAAGA-GASSER ${ }^{7 \odot}$, Carmen Australia Paredes Marcondes RIBAS $\mathbf{S}^{1,2 \odot}$

\begin{abstract}
Background: Studies with biomarkers in TMA (tissue microarray) have been showing important results regarding its expression in colon cancer. Aim: Correlate the expression profile of the $\mathrm{OPN}$ and $\mathrm{ABCB} 5$ biomarkers with the epidemiological and clinicopathological characteristics of the patients, the impact on the progression of the disease and the death. Method: A total of 122 CRC patients who underwent surgical resection, immunomarking and their relationship with progression and death events were evaluated. Result. The average age was $61.9( \pm 13.4)$ years. The cases were distributed in $42(35.9 \%)$ in the ascending/transverse colon, $31(26.5 \%)$ in the sigmoid, 27 in the rectum (23.1\%), 17 (14.5\%) in the descending colon. Most patients had advanced disease (stages III and IV) in 74 cases (60.9\%). There was a predominance of moderately differentiated tumors in 101 samples (82.8\%); despite this, the poorly differentiated subtype proved to be an independent risk factor for death in $70 \%$. Metastasis to the liver proved to be an independent risk factor for death in $75 \%$ (18/24), as well as patients with primary rectal tumors in $81.5 \%$ (22/27). Conclusion: The immunohistochemical expression of the OPN and ABCB5 markers was not associated with epidemiological and clinicopathological characteristics. Regarding the progression of disease and death, it was not possible to observe a correspondence relationship with the evaluated markers.
\end{abstract}

HEADINGS - ABCB5. Osteopontin. Colorectal cancer. Tumor biomarkers.

RESUMO - Racional: Estudos com biomarcadores com TMA (tissue microarray) vêm demostrando resultados importantes em relação à expressão de biomarcadores em câncer de cólon. Objetivo: Correlacionar o perfil de expressão dos biomarcadores OPN e ABCB5 com as características epidemiológicas e clinicopatológicas dos pacientes, o impacto na progressão de doença e no evento óbito. Método: Foram avaliados 122 pacientes de CCR submetidos à ressecção cirúrgica e à imunomarcação e relação com os eventos progressão e óbito. Resultado: A média de idade encontrada foi de $61,9( \pm 13,4)$ anos. Os casos distribuíram-se em $42(35,9 \%)$ no cólon ascendente/transverso, $31(26,5 \%)$ no sigmoide, 27 no reto $(23,1 \%), 17(14,5 \%)$ no cólon descendente. A maioria dos pacientes apresentou doença avançada (estadio III e IV) em 74 casos (60,9\%). Houve predomínio de tumor moderadamente diferenciado em 101 amostras (82,8\%); apesar disso, o subtipo pouco diferenciado mostrou-se como fator de risco independente para óbito em $70 \%$ dos casos. Metástase para o fígado mostrou-se fator de risco independente para óbito em $75 \%$ dos casos (18/24), assim como pacientes com tumores primários de reto em $81,5 \%$ (22/27). Conclusão: A expressão imunoistoquímica dos marcadores OPN e ABCB5 não apresentou associação com as características epidemiológicas e clinicopatológicas. Em relação à progressão de doença e evento óbito, não se conseguiu observar relação de correspondência com os marcadores avaliados.

DESCRITORES - ABCB5. Osteopontina. Câncer colorretal. Biomarcadores tumorais.

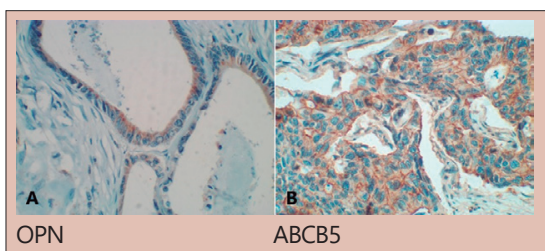

\section{Central message}

There are several uses for biomarkers in colorectal cancer, including in relation to more advanced cases that are resistant to chemotherapy, as is the case with $\mathrm{OPN}$ and $\mathrm{ABCB} 5$.

\begin{tabular}{|l|}
\hline Perspective \\
The use of biomarkers is under development for \\
evaluation in colorectal cancer. The study of these \\
and other biological markers, individually or together, \\
along the lines of a genetic panel, can improve the \\
indices of sensitivity and specificity both for assessing \\
disease progression in advanced cases and for early \\
diagnosis, through the assessment of injuries pre- \\
neoplastic, aiming at higher patient cure rates.
\end{tabular}

From the 'Medical Research Institute, Mackenzie Evangelical School of Paraná, Curitiba, PR, Brazil; Mackenzie Evangelical School of Paraná, Curitiba, PR, Brazil; 3 Department of Surgery, Mackenzie Evangelical School of Paraná, Curitiba, PR, Brazil; ${ }^{4}$ Department of Hematology, Mackenzie Evangelical School of Paraná, Curitiba, PR, Brazil; ${ }^{5}$ Department of Oncology, Mackenzie Evangelical School of Paraná, Curitiba, PR, Brazil; ${ }^{6}$ Department of Surgery, University Hospital Würzburg, Würzburg, Germany; ${ }^{7}$ Renal Division, Brigham and Woman's Hospital, Harvard Medical School, Boston, MA, USA; ${ }^{8}$ Evangelical Mackenzie University Hospital, Curitiba, Paraná, Brazil.

How to cite this article: Castoldi DF, Malafaia O, Santos-Neto PH, Postiglioni TV, Vasconcelos C, Bremer FP, Czeczko LEA, Gasser M, Waaga-Gasser AM, Ribas CAPM. Is there a clinical pathological correlation of colorectal adenocarcinoma with the immunohistochemical expression of OPN and ABCB5? ABCD Arq Bras Cir Dig. 2020;33(4):e1569. DOI: /10.1590/0102-672020200004e1569

\section{Correspondence:}

Diogo Francesco Castoldi

E-mail: diogocastoldi@gmail.com
Financial source: This work was carried out with the support of the Coordination for the Improvement of Higher Education Personnel - Brazil (CAPES) - Financing Code 001 and ${ }^{7}$ Renal Division, Brigham and Woman's Hospital, Harvard Medical School, Boston, MA, USA. Conflict of interest: none

Received for publication: 12/08/2020

Accepted for publication: 09/10/2020 
INTRODUCTION

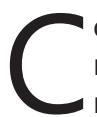
olorectal cancer (CRC) is the third most diagnosed malignancy in the world, considered one of the main causes of death ${ }^{15,22,32}$. Treatment consists of surgery, chemotherapy and radiation therapy. However, despite advances in treatment, the prognosis in cases of metastatic tumors remains reserved ${ }^{32,11}$.

Colorectal polyps are considered in most cases to be the precursors of RCC, according to the adenomaadenocarcinoma progression sequence, with variation in the speed of progression according to the characteristic of each poly $\mathrm{p}^{30}$. When not early diagnosed, and when operated on in emergency situations, it may present with major hydroelectrolytic changes, worsening the global prognose ${ }^{8}$.

Regarding molecular biology, there is great diversity, among which stand out the microsatellite instability, mutations in DNA repair genes and genetic changes such as APC, TP53, SMAD4, PIK3CA, KRAS, SOX919, just to name a few genes.

Minimally invasive blood markers have gained importance due to the facility for screening and monitoring patients $\mathrm{s}^{3,4,14}$. The carcinoembryonic antigen (CEA) is the most used in CCR, however its serum value may suggest, but not confirm the diagnosis or metastasis of cancer ${ }^{20,14}$.

There are few studies with biomarkers in microarray tissue blocks (TMA) in the literature; however, they have been showing significant results, as occurs in the expression of osteoponin (OPN): weak in healthy colonic cells, moderate in adenomas and strong in colon cancer ${ }^{24}$. OPN (Figure $1 \mathrm{~A}$ ) is an extracellular, multifunctional glycophosphoprotein, found in mineralized tissues such as extracellular matrix (ECM), body tissues and fluids, including blood, milk, urine, saliva, seminal fluid and bile $32,25,17,28$. It is produced in five isoforms by endothelial, neural cells, macrophages, monocytes, $T$ lymphocytes, responsible for the regulation of immune response, cell regeneration, vascularization, migration and motility ${ }^{1,2,26}$. It belongs to the Sibling family (Small IntegrinBinding Ligand N-linked Glycoprotein), a group of proteins located on chromosome 4, which have been observed in different tumor stages, indicating the potential for modulating the early tumoral behavior?

The expression of OPN is regulated by stimuli and pathways associated with CCR progression and metastasis. When derived from host cells, it induces cellular immunity and can reinforce anti-tumor protection by cytotoxic $T$ lymphocytes. When elevated, it can promote tumor progression and cell survival, neoangiogenesis and metastasis. This high induced expression of OPN in normal cells is observed to induce behavior similar to that of neoplastic cells, including cell invasion in vitro and metastasis in vivo ${ }^{25}$.

The $A B C$ genes constitute the largest family of transmembrane proteins, whose function is the transport of molecules with consumption of $A \mathrm{AP}^{6}$. The $A B C B 5$ gene (Figure $1 B$ ), belongs to the superfamily $A B C^{31}$, located on chromosome 7, short arm, loci $14^{6}$, has varied expression in tissues such as melanocytes, pigmented epithelium of the retina and breast ${ }^{12}$, and increased expression in breast, colorectal and melanoma cancer malignant ${ }^{12,9,23}$. Most $A B C$ genes transport substances from the cytoplasm to the cell exterior or to intracellular compartments ${ }^{6}$, through the drug efflux mechanism, presenting a protective effect of cancer stem cells against the attack of chemotherapeutic agents, for example.

North American data show a five-year survival rate of $88.1 \%$ and $12.6 \%$ for stages I and IV of the disease, respectively 5 . Considering the above, the evaluation of the expression by immunohistochemistry of OPN and ABCB5 proteins in tissue using CCR TMA can help in a better prognosis and early detection of these tumors. Diagnostic and therapeutic strategies are necessary, which requires a greater understanding of the molecular mechanisms of RCC and the use of biomarkers in order to improve the prognosis through the early detection of these tumors ${ }^{11,20}$.

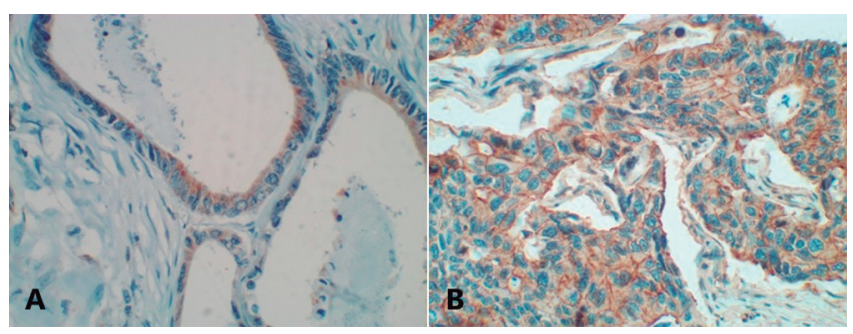

FIGURE 1 - Colon adenocarcinoma: A) OPN showing cytoplasmic positivity and in brown the region of its marking on the cytoplasmic membrane is observed; $B) A B C B 5$ showing positivity of the cytoplasmic membrane and in brown the region of its marking inside and cytoplasmic membrane (400x) is observed

The aim of this study was to correlate the expression profile of the OPN and $A B C B 5$ biomarkers with the epidemiological and clinicopathological characteristics of the patients, the impact on disease progression and on the death event.

\section{METHODS}

This is an observational, retrospective and single-center analytical study, of the case-control type. The research was previously approved by the Research Ethics Committee of Faculdade Evangélica Mackenzie do Paraná under no. 1,999,670.

\section{Patients and tissues}

Patients were selected from Hospital Universitário Evangélico Mackenzie in Curitiba, PR, Brazil, of both genders, over 18 years old, with a diagnosis of colorectal adenocarcinoma, were seen and treated during the period of 2010 and 2015, whose paraffin blocks confirmed the diagnosis. These blocks should be eligible for further fractionation for evaluation by TMA, and the medical record should be available at the hospital. These blocks and slides were sent for histological confirmation by a second pathologist and were subsequently sent for immunostaining.

The exclusion criteria were: age under 18; diagnosis of colorectal cancer not adenocarcinoma; paraffin blocks could not be found or manipulated; absence of clinical and epidemiological data in medical records.

The application of the inclusion and exclusion criteria resulted in 122 patients, this being the final sample of the study.

\section{Defining groups}

From the data collection, patients were divided into three distinct groups, associated with the OPN and ABCB5 markers as negative (control), positive (case 1) and inconclusive (case 2) for their expression. From this division, patients were also subdivided into patients with local and advanced disease.

\section{Block making and immunohistochemistry}

The Tissue Tek Quick-ArrayTM manual device was used to make the multi-sample blocks, which contains coupled clamps whose diameters vary from $1.0 \mathrm{~mm}$ to 3.0 $\mathrm{mm}$, responsible for extracting the desired area for the immunohistochemistry. These blocks made it possible to obtain up to 60 fragments of neoplastic tumor tissue. From this point on, they were submitted to the immunoperoxidase 
technique, performed on a Benchmark UltraTM instrument, with integrated 3 in 1 processing, including dewaxing, rehydration and antigenic recovery, with Cell Conditioning 1 (high $\mathrm{pH}$ ) and Cell Conditioning 2 (low pH) buffers. ). The incubation with antibodies of the $A B C B 5$ marker (clone $5 \mathrm{H} 3 \mathrm{C} 6$ manufacturer Genetex) in the 1: 100 dilution and the OPN marker (polyclonal, manufacturer Medaysis) in the 1:20 dilution, lasted between 16-20 min at room temperature. The amplification was performed by Ultraview Universal DAB Detection Kit ${ }^{\mathrm{D}}$. All processing was carried out on a Ventana Benchmark UltraTM automated platform. Positive internal and external controls attested the fidelity of the reactions. After marking the primary antibodies, the reading was done through an amplifier. Samples that showed labeling by the antibody were considered positive and negative those that were not marked.

\section{Data collect}

After selecting the cases, clinical information was collected. For this purpose, the following databases were used: electronic medical record system (PAGU), physical ambulatory medical record, chemotherapy release guides (APACs, when available) and official pathological report of colorectal tumors. Telephone contact was followed for additional information, when possible. The data were distributed in an Excel table according to the following standardized protocol: age, gender, date of diagnosis, report of pathological anatomy, staging, treatments used (surgery, chemotherapy and / or radiotherapy), presence and location of lymph node or distant metastases, existence of disease progression, date of last visit and / or death.

\section{Statistical analysis}

The data were analyzed using the computer program Stata / SE v.14.1. StataCorpLP, USA. Quantitative variables were described as means, standard deviations, medians, minimum and maximum values. Categorical variables were described by frequencies and percentages. Fine and Gray models were adjusted to analyze factors related to the time until disease progression (Pevent) considering death as a competitive risk. After adjustment, the estimated association measure was the subdistribution hazard ratio (SHR). For the survival analysis, Cox regression models were adjusted, and the hazard ratio values were estimated. For both models, the Wald test was used to assess the significance of the variables. Values of $p<0.05$ indicated statistical significance.

RESULTS

The average age found was $61.9 \pm 13.4$ years. In the total sample, there was a male / female ratio of 1.06 : 1 , with a higher prevalence of disease in the fifth and sixth decade of life (56.6\%). The cancer incidence according to the topography was 42 cases (35.9\%) in the ascending / transverse colon, 31 $(26.5 \%)$ in the sigmoid, 27 in the rectum $(23.1 \%), 17(14.5 \%)$ in the descending colon and five indeterminate. Regarding the degree of differentiation, there was a predominance of moderately differentiated tumors in 101 samples (82.8\%), little differentiated in 10 (8.2\%), well differentiated in eight (6.6\%), and three $(2.4 \%)$ of undetermined. The most common site of metastasis at diagnosis was in the liver $(n=24,19.7 \%)$, peritoneum ( $n=9,7.4 \%)$, lung $(n=5,4.1 \%)$ and another organ $(n=11.9 \%)$

Patients were classified according to their clinical stage, from 0 to IV, respecting the classification of the 6th edition of the Cancer Staging Manual (AJCC) of 2002, as used at the time when patients were seen (Table 1), with a predominance of the most advanced cases, stages III and IV with 74 cases $(60.9 \%)$.
TABLE 1 - Distribution according to clinical stage

\begin{tabular}{|c|c|c|}
\hline UICC & $\mathbf{n}$ & $\%$ \\
\hline 0 & 1 & 0,8 \\
\hline I & 14 & 11,5 \\
\hline II & 33 & 27 \\
\hline III & 39 & 32 \\
\hline IV & 35 & 28,7 \\
\hline Total & 122 & 100 \\
\hline
\end{tabular}

The ABCB5 control group was $14(11.5 \%)$, case 1 of 74 patients $(60.7 \%)$ and case 2 of $34(27.8 \%)$, while in the OPN group the control was $53(43,4 \%)$, case 1 of $41(33.6 \%)$ and case 2 of 28 (23.3\%, Table 3$)$. No statistical significance was observed in the presence or absence of the $A B C B 5$ and OPN markers in relation to age, time of diagnosis of patients, gender, degree of differentiation, clinical staging or metastasis anywhere. The evaluation of the agreement between the ABCB5 and OPN markers (Table 2) was shown to be weak, with $24.6 \%$ of agreement in both positive ( $n=$ $30)$ and $5.7 \%(n=7)$ in both negative.

TABLE 2 - Concordance between markers

\begin{tabular}{|c|c|c|c|c|}
\hline \multirow{2}{*}{ OPN } & \multicolumn{3}{c}{ ABCB5 } & \multirow{2}{*}{ Total } \\
\cline { 2 - 4 } Negative & Negative & Positive & Inconclusive & \\
\hline \multirow{2}{*}{ Positive } & 7 & 37 & 9 & 53 \\
\hline Inconclusive & $4,70 \%$ & $30,30 \%$ & $7,40 \%$ & \\
\hline Total & $4,90 \%$ & $24,60 \%$ & $4,10 \%$ & 41 \\
\hline & 1 & 7 & 20 & 28 \\
\hline
\end{tabular}

Concurrent cases = 57 (46.7\%); discordant cases = 65 (40.2\%); Kappa coefficient of agreement: 0.22 (weak agreement)

The $A B C B 5$ marker in cases of local disease was more associated with death in case 1 group [26/54 vs. 6/10; p $=0.161(95 \% \mathrm{Cl} 0.21-1.29)]$, case group 2 [13/23 vs. $6 / 10$; $\mathrm{p}=0.631(95 \% \mathrm{Cl} 0.3-2.08)]$ and patients with advanced disease, both in case 1 group [14/20 vs. 4/4; $p=0.509$ (95\% Cl 0.22-2.13)] as for case group 2 [5/11 vs. 4/4; $p=$ $0.122(95 \% \mathrm{Cl} 0.09-1.32)]$, all of which were not statistically significant (Table 3).

TABLE 3 - Relationship of marker expression with clinical stage

$\mathrm{ABCB} 5$

\begin{tabular}{|c|c|c|c|c|c|c|}
\hline Variable & Classif & $\mathrm{n}$ & $\%$ of death & $\mathrm{p}^{*}$ & $\mathrm{HR}$ & $\mathrm{Cl} 95 \%$ \\
\hline $\begin{array}{c}\text { Stage } \\
\text { O/I/II }\end{array}$ & Negativo (ref) & 10 & $6(60,0)$ & & & \\
& Positivo & 54 & $26(48,1)$ & 0,161 & 0,52 & $0,21-1,29$ \\
\hline & Inconclusivo & 23 & $13(56,5)$ & 0,631 & 0,79 & $0,30-2,08$ \\
\hline \multirow{2}{*}{$\begin{array}{c}\text { Stage } \\
\text { III/IV }\end{array}$} & Pegativo (ref) & 4 & $4(100)$ & & & \\
& Positivo & 20 & $14(70,0)$ & 0,509 & 0,68 & $0,22-2,13$ \\
\hline
\end{tabular}

*Modelo de regressão de Cox e teste de Wald, $p<0,05$

\begin{tabular}{c|c|c|c|c|c|c|}
\multicolumn{2}{c}{ OPN } & & & & & \\
Variable & Classif & $\mathbf{n}$ & $\%$ of death & $\mathbf{p}^{*}$ & HR & Cl $95 \%$ \\
\hline $\begin{array}{c}\text { Stage } \\
\text { 0/I/II }\end{array}$ & Negativo (ref) & 40 & $20(50,0)$ & & & \\
& Positivo & 29 & $14(48,3)$ & 0,844 & 0,93 & $0,47-1,86$ \\
\hline \multirow{2}{*}{$\begin{array}{l}\text { Inconclusivo } \\
\text { III/IV }\end{array}$} & Negativo (ref) & 13 & $11(61,1)$ & 0,240 & 1,57 & $0,74-3,32$ \\
\hline & Positivo & 12 & $9(76,9)$ & & & \\
\hline & Inconclusivo & 10 & $4(40,0)$ & 0,949 & 1,03 & $0,41-2,60$ \\
\hline
\end{tabular}

* Cox regression model and Wald test, $p<0,05$ 
Regarding the OPN marker, similar data were obtained in the local disease associated with the case 2 group, compared to the control group $[20 / 40$ vs. $11 / 18 ; p=0.24(95 \% \mathrm{Cl}$ 0.74-3.32)]. In patients with advanced disease, there was a higher death rate in the control group compared to the case 1 group [9/12 vs. 10/13; $p=0.949(95 \% \mathrm{Cl} 0.41-2.6)]$ and case group 2 [4/10 vs. 10/13; $p=0.865$ (95\% Cl 0.27-2.96)], all of which were not statistically significant (Table 3 ).

When comparing groups with respect to disease progression of the $A B C B 5$ marker, higher rates of progression occurred among patients in the case 1 group [30/74 vs. 2/14; $\mathrm{p}=0.141(95 \% \mathrm{Cl} 0.69-13.7)]$ and case group 2 [11/34 vs $2 / 14 ; p=0.229$ (95\% Cl 0.54-12.8)], however did not result in statistically significant. Regarding the OPN marker, there were also higher rates in the case 1 group [16/41 vs. $17 / 53$; $p=0.541(95 \% \mathrm{Cl} 0.63-2.41)]$ and case group 2 [10/28 vs $17 / 53 ; p=0.404(95 \% \mathrm{Cl} 0.64-3.03)]$, also not showing statistically significant results (Table 4).

TABLE 4 - Analysis of variables in relation to disease progression

\begin{tabular}{|c|c|c|c|c|c|c|}
\hline Variable & Classification & $\mathrm{n}$ & $\begin{array}{c}\% \text { of } \\
\text { cases with } \\
\text { progression }\end{array}$ & $\mathrm{p}^{*}$ & SHR & $\mathrm{Cl} 95 \%$ \\
\hline \multirow{3}{*}{ ABCB5 } & Negative (ref) & 14 & $2(14,3)$ & & & \\
\hline & Positive & 74 & $30(40,5)$ & 0,141 & 3,08 & $0,69-13,7$ \\
\hline & Inconclusive & 34 & $11(32,2)$ & 0,229 & 2,64 & $0,54-12,8$ \\
\hline \multirow{3}{*}{ OPN } & Negative (ref) & 53 & $17(32,1)$ & & & \\
\hline & Positive & 41 & $16(39,0)$ & 0,541 & 1,23 & $0,63-2,41$ \\
\hline & Inconclusive & 28 & $10(35,7)$ & 0,404 & 1,39 & $0,64-3,03$ \\
\hline
\end{tabular}

SHR $=$ subdistribution hazard ratio; $95 \% \mathrm{Cl}=95 \%$ confidence interval; ${ }^{*}=$ Fine and Gray model and Wald test, $\mathrm{p}<0,05$

In the assessment of factors associated with death for the marker $A B C B 5$, a higher rate of evolution was observed in the control group in relation to case 1 [40/74 vs. 10/14; $\mathrm{p}=0.089(95 \% \mathrm{Cl} 0.27-1.1)]$ and case group 2 [18/34 vs. $10 / 14 ; p=0.239(95 \% \mathrm{Cl} 0.29-1.36)]$, both not statistically significant. Similar results were obtained in the OPN marker, with higher rates in the control group compared to the case 1 group [23/41 vs. $30 / 53 ; p=0.982(95 \% \mathrm{Cl} 0.58-1.74)]$ and case group 2 [15/28 vs. 30/53; $\mathrm{p}=0.403$ (95\% Cl 0.7-2.46)], without statistical significance (Table 5 ).

TABELA 5 - Analysis of variables in relation to the death event

\begin{tabular}{|c|c|c|c|c|c|c|}
\hline Variabel & Classification & $\mathrm{n}$ & $\%$ of death & $\mathrm{p}^{*}$ & $\mathrm{HR}$ & $\mathrm{Cl} 95 \%$ \\
\hline \multirow{2}{*}{ ABCB5 } & Negative (ref) & 14 & $10(71,4)$ & & & \\
& Positive & 74 & $40(54,1)$ & 0,089 & 0,54 & $0,27-1,10$ \\
\hline \multirow{3}{*}{ OPN } & Inconclusive & 34 & $18(52,9)$ & 0,239 & 0,63 & $0,29-1,36$ \\
\hline & Negative (ref) & 53 & $30(56,6)$ & & & \\
\cline { 2 - 7 } & Positive & 41 & $23(56,1)$ & 0,982 & 1,01 & $0,58-1,74$ \\
\hline & Inconclusive & 28 & $15(53,6)$ & 0,403 & 1,31 & $0,70-2,46$ \\
\hline
\end{tabular}

* $=$ Cox regression model and Wald test, $p<0.05$; Progression event variable was included as time-dependent

\section{DISCUSSION}

Follow-up time was longer in stage II patients and shorter in stages 0 / I. This context can be explained by the loss of follow-up, the high cure rate, or even the loss of follow-up from the patient. The shortest follow-up periods were seen in stages III / IV, due to the natural evolution of the disease followed by death.

It is possible was raised that the levels of OPN in blood samples or tumor specimen could be valuable in predicting the prognosis of carcinomas. This fact motivated a meta-analysis to evaluate the expression of OPN both in progression and in prognosis, and its usefulness as a prognostic biomarker was verified, besides being a potential therapeutic target in RCC ${ }^{32}$.

It was previously demonstrated that the high level of expression of OPN mRNA had clinicopathological significance and prognosis in RCC. The level of expression of the OPN protein in CCR cells and corresponding normal tissue samples was evaluated. Their results indicated that the negative regulation of OPN could suppress both in vitro proliferation and in vivo tumorigenicity ${ }^{15}$. The expression of OPN in a CCR cell in this study was positive in $39 \%$ of cases of progression and $56.1 \%$ of deaths. However, this data was not statistically significant.

In a study with 84 CRC patients, it was found that the level of transcription of OPN and its overexpression were responsible for inducing chemo-resistance to treatment with oxaliplatin. This overexpression was related to metastasis and decreased survival rate ${ }^{27}$. In this sample, a rate of $39 \%$ of disease progression and $56.1 \%$ of cases of death were observed, which, despite not having statistical significance, is believed to be related to the more advanced cases and which presented some type of chemoresistance to the treatment offered. . In 59.7\% (46/77) of the times when chemotherapy was a treatment option, oxaliplatin was provided both in neoadjuvancy and in adjuvance and palliation.

In a group of more than 200 CCR stage II patients, it was noted that the level of OPN in the tumor tissue was useful in the detection of CCR, but it was not related to prognosis $^{21}$. In this research, 33 stage II cases (27\%) were observed, of which 10 (30.3\%) presented disease progression and 15 (45.4\%) progressed to death. Despite the absence of statistical significance, these are numbers that cannot be ignored.

Likui et al. reported that the level of OPN mRNA expression in cells or tissues with RCC was significantly higher than in non-tumoral epithelial cells of the colon ${ }^{15,18}$. It has also been reported that the value of OPN mRNA expression in the CCR enhances clinicopathological and / or prognostic findings. In addition, it was shown that the level of OPN mRNA expression in RCC cells was significantly associated with lymph node metastasis, lymphatic invasion, venous invasion and consequently TNM staging (advanced stages - III / IV $)^{16}$. This increase in OPN expression was observed in this research, with a predominance in cases of local disease (stage $0 /$ I / II), but without statistical significance.

When analyzing the data related to the presence of the ABCB5 marker, its positivity was identified in $60.7 \%$ (n $=74$ ) of the cases of a total of 122 patients. Despite this high incidence of positive $A B C B 5$ expression alone, there was poor corelation between $A B C B 5$ and $O P N$, with only $24.6 \%$ of positive cases.

The present sample did not achieve statistical significance for the epidemiological data related to $A B C B 5$; however, there was a correlation between positivity of this marker with a diagnosis of $C R C$ and death. When the positive relationship between $A B C B 5$ and local or advanced disease was assessed, there was a greater positivity of the marker with stage III and IV (more advanced disease), again without statistical significance. Two possibilities were raised by Kugimiya et al. which help to justify this finding: the first would be the survival of CCR cells treated with 5-FU and which showed high $A B C B 5$ expression; the other would be that the use of 5-FU increases the expression of the marker in some cells, and with that they can stay alive ${ }^{13}$.

It was found that in cases that required chemotherapy, $100 \%$ were treated with fluoropyrimidine at some point, and showed $40.5 \%$ disease progression and $54.1 \%$ death. There was agreement in the findings above and in the literature, especially in situations in which the marker functions as a mediator of resistance to multiple drugs, such as $5-\mathrm{FU}^{10}$, and especially when used as monotherapy ${ }^{29}$. 


\section{CONCLUSION}

The immunohistochemical expression of the OPN and $A B C B 5$ markers was not associated with epidemiological and clinicopathological characteristics. Regarding the progression of the disease and death, it was not possible to observe a correspondence relationship with the evaluated markers.

\section{REFERENCES}

1. Ashkar S, Weber GF, Panoutsakopoulou V, Sanchirico ME, Jansson M Zawaideh $\mathrm{S}$, et al. Eta-1 (osteopontin): an early component of type-1 (cell-mediated) immunity. Science. 2000 Feb;287(5454):860-4.

2. Bandopadhyay M, Bulbule A, ButtiR, Chakraborty G, Ghorpade P, Ghosh $P$, et al. Osteopontin as a therapeutic target for cancer. Expert Opin Ther Targets. 2014 Aug;18(8):883-95.

3. BarchiLC, Ramos MFKP, DiasAR, Andreollo NA, WestonAC, Lourenço LG, et al. II Brazilian Consensus on Gastric Cancer Association. ABCD Arq Bras Cir Dig (São Paulo) [Internet]. 2020 [cited 2020 Aug 26];33(2). Available from: http://www.scielo.br/scielo.php?script=sci_arttext\&pid=S0102$67202020000200306 \&$ tlng $=$ en

4. Coimbra FJF, Torres OJM, Alikhanov R, Agarwal A, Pessaux P, Fernandes E de SM, et al. Brazilian Consensus on Incidental Gallblader Carcinoma. ABCD Arq Bras Cir Dig (São Paulo) [Internet]. 2020 [cited 2020 Aug 26];33(1). Available from: http://www.scielo.br/scielo.php?script=sci_ arttext\&pid=S0102-67202020000100306\&tIng=en

5. Cronin KA, Lake AJ, Scott S, Sherman RL, Noone AM, Howlader N, et al Annual Report to the Nation on the Status of Cancer, part I: National cancer statistics. Cancer. 2018 Jul 1;124(13):2785-800.

6. Dean $M$, Hamon $Y$, Chimini $G$. The human ATP-binding cassette (ABC) transporter superfamily. J Lipid Res. 2001;42(7):1007-17.

7. Fisher LW, Jain A, Tayback M, Fedarko NS. Small integrin binding ligand $\mathrm{N}$-linked glycoprotein gene family expression in different cancers. Clin Cancer Res. 2004 Dec;10(24):8501-11.

8. Freire EG, Albuquerque JCS, Leal IP, Sousa NA, Graça JRV da, et al. Eeffet of chronic renal dysfunction on the permeability of the colon to water and electrolytes: experimental study on rats. ABCD Arq Bras Cir Dig (São Paulo) [Internet]. 2019 [cited 2020 Aug 27];32(4). Available from: http://www.scielo.br/scielo.php?script=sci_arttext\&pid=S0102$67202019000400306 \&$ tIng $=$ en

9. Gambichler T, Petig AL, Stockfleth E, Stücker M. Expression of SOX10, $A B C B 5$ and $C D 271$ in melanocytic lesions and correlation with survival data of patients with melanoma. Clin Exp Dermatol. 2016:41(7):709-16.

10. Guo Q, Grimmig T, Gonzalez G, Giobbie-Hurder A, Berg G, Carr N, et al. ATP-binding cassette member B5 (ABCB5) promotes tumor cell invasiveness in human colorectal cancer Downloaded from. 2018; Available from: http://www.jbc.org/cgi/doi/10.1074/jbc.RA118.003187

11. Jemal A, Siegel R, Ward E, Hao Y, Xu J, Thun MJ. Cancer statistics, 2009. CA Cancer J Clin. 2009:59(4):225-49.

12. Kleffel S, Lee N, Lezcano C, Wilson BJ, Sobolewski K, Saab KR, et al ABCB5-TargetedChemoresistanceReversal InhibitsMerkelCellCarcinoma Growth. J Invest Dermatol. 2016;136(4):838-46.

13. Kugimiya N, Nishimoto A, Hosoyama T, Ueno K, Enoki T, Li T, et al. The c-MYC-ABCB5 axis plays a pivotal role in 5-fluorouracil resistance in human colon cancer cells. J Cell Mol Med. 2015;19(7):1569-81.

14. Lee IK, Kim DH, Gorden DL, Lee YS, Sung NY, Park G-S, et al. Prognostic value of CEA and CA 19-9 tumor markers combined with cytology from peritonealfluidincolorectalcancer.AnnSurgOncol.2009Apr;16(4):861-70.

15. Likui W, Hong W, Shuwen Z, Yuangang Y, Yan W. The potential of osteopontin as a therapeutic target for human colorectal cancer. J Gastrointest Surg. 2011 Apr;15(4):652-9.
16. Likui W, Hong W, Shuwen Z. Clinical significance of the upregulated osteopontin mRNA expression in human colorectal cancer.J Gastrointest Surg. 2010 Jan;14(1):74-81.

17. Mack PC, Redman MW, Chansky K, Williamson SK, Farneth NC, Lara PNJ, et al. Lower osteopontin plasma levels are associated with superior outcomes in advanced non-small-cell lung cancer patients receiving platinum-based chemotherapy: SWOG Study S0003. J Clin Oncol. 2008 Oct:26(29):4771-6

18. Mole DJ, O'Neill C, Hamilton P, Olabi B, Robinson V, Williams L, et al. Expression of osteopontin coregulators in primary colorectal cancer and associated liver metastases. Br J Cancer. 2011 Mar;104(6):1007-12.

19. Muzny DM, Bainbridge MN, Chang K, Dinh HH, Drummond JA, Fowler $\mathrm{G}$, et al. Comprehensive molecular characterization of human colon and rectal cancer. Nature [Internet]. 2012;487(7407):330-7. Available from: http://dx.doi.org/10.1038/nature11252

20. Ng L, Wan TM-H, Lam CS-C, Chow AK-M, Wong SK-M, Man JH-W, et al. Post-operative plasma osteopontin predicts distant metastasis in human colorectal cancer. PLoS One. 2015;10(5):e0126219.

21. Nitsche U, Rosenberg R, Balmert A, Schuster T, Slotta-Huspenina J, Herrmann $P$, et al. Integrative marker analysis allows risk assessment for metastasis in stage II colon cancer. Ann Surg. 2012 Nov;256(5):763-71; discussion 771.

22. Overgaard J, Eriksen JG, Nordsmark M, Alsner J, Horsman MR. Plasma osteopontin, hypoxia, and response to the hypoxia sensitiser nimorazole in radiotherapy of head and neck cancer: results from the DAHANCA 5 randomised double-blind placebo-controlled trial. Lancet Oncol. 2005 Oct;6(10):757-64.

23. Schatton T, Murphy GF, Frank NY, Yamaura K, Waaga-Gasser AM, Gasser $\mathrm{M}$, et al. Identification of cells initiating human melanomas. [cited 2017 Apr 28]; Available from: https://www.nature.com/nature/journal/v451/ n7176/pdf/nature06489.pdf

24. Valcz G, Sipos F, Krenács T, Molnár J, Patai Á V., Leiszter K, et al. Elevated osteopontinexpressionand proliferative/apoptotic ratio in the colorectal adenoma-dysplasia-carcinoma sequence. Pathol Oncol Res. 2010 Dec:16(4):541-5.

25. Wai PY, Kuo PC. Osteopontin: regulation in tumor metastasis. Cancer Metastasis Rev. 2008 Mar:27(1):103-18.

26. WeberGF,AshkarS, CantorH. Interaction betweenCD44 and osteopontin as a potential basis for metastasis formation. Proc Assoc Am Physicians. 1997 Jan;109(1):1-9.

27. Weber GF. The cancer biomarker osteopontin: combination with other markers. Cancer Genomics Proteomics. 2011;8(6):263-88.

28. Wei R, Wong JPC, Kwok HF. Osteopontin -- a promising biomarker for cancer therapy. J Cancer. 2017;8(12):2173-83.

29. Wilson BJ, Schatton T, Zhan Q, Gasser M, Ma J, Saab KR, et al. ABCB5 identifies a therapy-refractory tumor cell population in colorectal cancer patients. Cancer Res August [Internet]. 2011 [cited $2018 \mathrm{Apr}$ 6];1(7115):5307-16.Availablefrom:https://www.ncbi.nlm.nih.gov/pmc/ articles/PMC3395026/pdf/nihms302813.pdf

30. Yang C-Y, Tseng J-Y, Chen C-F, Chou T-Y, Gao H-W, Hua C-L, et al Genome-widecopynumberchangesandCD133expressioncharacterized distinct subset of colon polyps: differentiation between incidental polyps and cancer-associated polyps. Int J Colorectal Dis [Internet]. 2015 Dec 24 [cited 2019 Jul 10];30(12):1617-26. Available from: http://link.springer. com/10.1007/s00384-015-2319-2

31. Yao J, Yao X, Tian T, Fu X, Wang W, Li S, et al. ABCB5-ZEB1 Axis Promotes Invasion and Metastasis in Breast Cancer Cells. Oncol Res Featur Preclin Clin Cancer Ther. 2017;25(3):305-16.

32. Zhao M, Liang F, Zhang B, Yan W, Zhang J. The impact of osteopontin on prognosis and clinicopathology of colorectal cancer patients: a systematic meta-analysis. Sci Rep. 2015 Aug;5:12713. 